\title{
Measurements of surface flatness distortions using machine vision inspection system
}

\author{
Pomiary odchyłki płaskości powierzchni swobodnej \\ z użyciem systemu wizyjnego
}

\author{
ANNA ZAWADA-TOMKIEWICZ \\ DARIUSZ TOMKIEWICZ \\ LESŁAW WILK *
}

DOI: https://doi.org/10.17814/mechanik.2017.12.196

\begin{abstract}
The use of a vision system for evaluating the flatness distortion of float glass under thermal treatment in a horizontal process is presented. The possibility of evaluation of such parameters as overall bow, roller wave and edge lift was analysed for a pane of glass taken from production.

KEYWORDS: float glass, thermally toughened soda lime silicate safety glass, overall bow, roller wave distortion, edge lift
\end{abstract}

The problem recognized in the work was the use of a vision system to assess the flatness of thermally toughened sodium-lime-silicate glass. The properties of such glass have been defined in the EN 12150-1 and EN 12150-2 standards. The main requirement for thermally tempered glass intended for the use in architecture is that it does not visually show any distortion. Subjecting glass EN 572-1 and EN 572-2 to heat treatment makes it safe, but at the same time, some distortions occur.

The above-mentioned standards $[1 \div 4]$ recognize two sets of disturbances depending on the method of heat treatment:

- for horizontal process (in which glass is supported on horizontal rolls) - overall bow as well as local bow (roller wave and edge lift),

- for vertical hardening process (in which the glass is suspended) - overall bow and local bow.

\section{Classic method of measuring the surface flatness}

The EN 12150-1 standard defines the overall and local bow of glass (fig. 1).

To assess the overall bow of glass, the glass pane is placed on the long side in a vertical position on two supports. Next, the feeler measures the maximum distance of the ruler from the concave surface of the glass. The measure of the overall bow is value of this distance divided by the length of diagonal or side (depending on where it occurs).

The local bow of the glass is evaluated parallel to each periphery in the middle of the roller wave and $25 \mathrm{~mm}$ from the edge (edge lift). In both cases, the local bow is estimated at $300 \mathrm{~mm}$. It should be noted that the roller

\footnotetext{
* Dr hab. inż. Anna Zawada-Tomkiewicz prof. nadzw (anna.zawada-tomkiewicz@tu.koszalin.pl), prof. dr hab. inż. Dariusz Tomkiewicz (dariusz.tomkiewicz@tu.koszalin.pl), Lesław Wilk (leslaw.wilk @tu.koszalin.pl) - Wydział Mechaniczny Politechniki Koszalińskiej
}

wave local bow is characteristic of the horizontal process of thermal hardening. The maximum permissible values of the overall and local bows are shown in fig. 1.
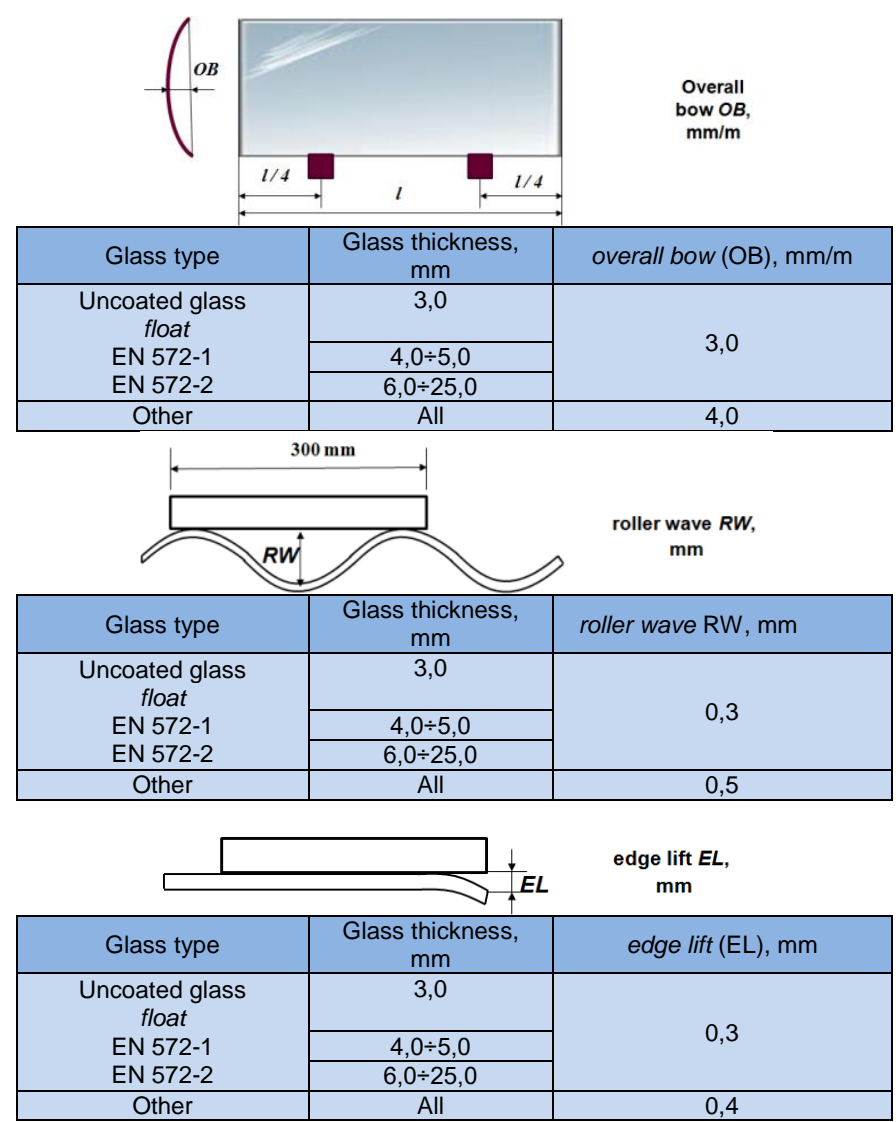

Fig. 1. Flatness distortion of tempered glass panel surface

Free surface measurement procedure with a vision system

The main objective of the vision system design is to assess the flatness of the glass immediately after the heat treatment with the intention of providing information to the furnace operator, whether the heat treatment conditions have been correctly selected. The parameters obtained with the use of the vision system are to support the heat treatment process and the subsequent process of joining the laminated glass.

In this case, the main assumption for developing the system is the application of online measurement methods, without operator intervention and without 
interfering with the course of the process. The second assumption is based on the use of the optical method, which means that the measurement is non-contact, fast and at the same time, not destructive for the object being measured. The most important thing, however, is that the classic measurement is made only on a small sample of data, while the use of the vision system allows measurement and evaluation of the entire production range.

To verify the concept of the measurement method, a machine vision inspection system was developed. It is a prototype device that will be used in industry after testing and calibration. The laboratory set consists of a belt conveyor, on which a glass pane, lighting system, digital camera with an optical system and computer for acquiring and processing data, were placed. The conveyor belt control system enables the glass pane to be displaced and positioned to the nearest $0.1 \mathrm{~mm}$. The glass pane was illuminated with a specially designed lighting system, and then reflected light was analyzed and the location of the point in space was determined on this basis.

\section{Measurement results and their analysis}

A vision system was used to control the sheets of tempered glass. Due to the use of image processing methods, it was possible to obtain a cloud of free surface points, and then its model and values of distortions overall bow, roller wave and edge lift.

However, before measurements were made to verify the suitability of the system, its measurement capability was evaluated. A "very flat" pane of glass was used for this. It was a test prepared from sodium-lime-silica glass before heat treatment. The requirement for glass consisted in the fact that the standard deviation of each parameter was lower than the determined tolerance threshold. The comparison for individual parameters of deviations measured horizontally was carried out according to the MSA procedure. According to the procedure, for the system to have measurement capability: number of data categories $n d c>5$, and repeatability and reproducibility ratio $\% G R R<10 \%$ for each determined parameter.

It was found that the system has the appropriate measurement capacity, because for the total bow, ndc = 8.1 and $\% G R R=9 \%$, for roller wave, $n d c=8$ and $\% G R R$ $=1 \%$, and for edge lift, $n d c=5.1$ and $\% G R R=1 \%$. a)

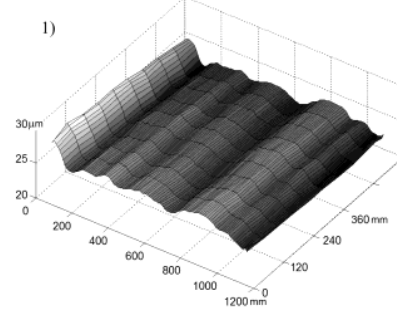

b)

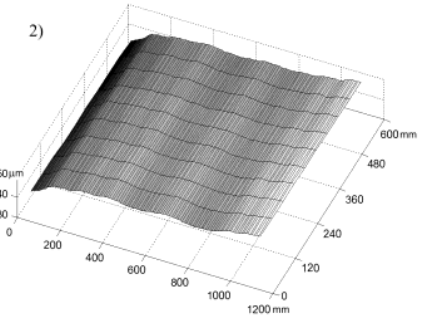

Fig. 2. Example of raw measurement data of thermal toughened sheets of $6 \mathrm{~mm}$ thick glass taken in a horizontal position: a) in the initial position from the furnace, $b$ ) in the reverse position

The main idea of the developed vision system was the ability to assess the flatness of the tempered glass immediately after the process. It was important to use the system, when process or glass parameters changed. The measurement was made in a horizontal position, as the panes flow in the real process. Therefore, all measurement conditions for the overall bow were not perserved. Hence the necessity to compare the results of the object measurement in two horizontal positions - in the output system from the furnace (a) and in the reverse system (b in fig. 2).

The measured surface data of the glass pane was analyzed in order to calculate three parameters of deviations - overall bow measured in the horizontal position of the glass $O B h$, roller wave $(R W)$ and the lift edge $(E L)$.

The graphs in fig. 3 show that in the case of the overall bow, the results differ, while in the case of local bow, the horizontal arrangement does not significantly affect the parameter values. A comparison of the measurement results made with an optical method (a cloud of measurement data for the whole glass panes) and reference measurements (individual contact measurements) is given in the Table.
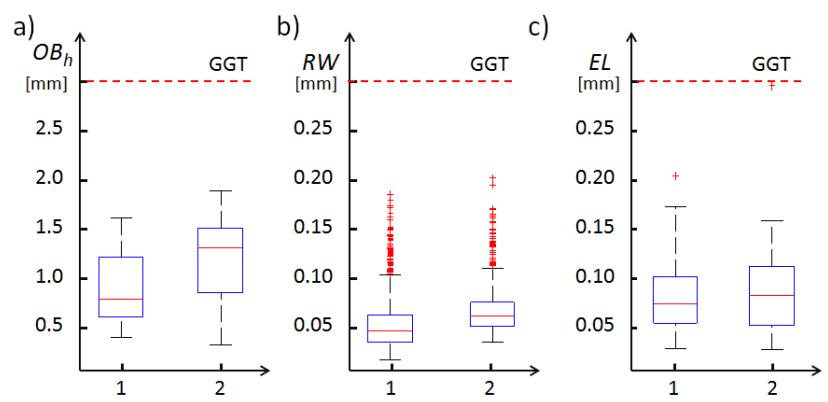

Fig. 3. Repeatability of measurements: a) $O B h$, b) $R W$, c) $E L$ in horizontal arrangement (see fig. 2a and b)

TABLE. List of measurement results (glass thickness $6 \mathrm{~mm}$ )

\begin{tabular}{|c|c|c|c|c|}
\hline \multirow{2}{*}{$\begin{array}{c}\text { Flat- } \\
\text { ness } \\
\text { devia- } \\
\text { tion }\end{array}$} & \multirow{2}{*}{$\begin{array}{l}\text { Maximum } \\
\text { value, } \\
\mathrm{mm}\end{array}$} & \multirow{2}{*}{$\begin{array}{l}\text { Classic } \\
\text { method } \\
\text { measure- } \\
\text { ment, mm }\end{array}$} & \multicolumn{2}{|c|}{$\begin{array}{l}\text { Measurement using a } \\
\text { vision system in a } \\
\text { horizontal glass posi- } \\
\text { tion } \mathrm{mm}\end{array}$} \\
\hline & & & $\begin{array}{c}\text { In the } \\
\text { starting } \\
\text { position } \\
\text { from the } \\
\text { furnace }\end{array}$ & $\begin{array}{l}\text { In the } \\
\text { reverse } \\
\text { system }\end{array}$ \\
\hline $\begin{array}{c}\text { Overall } \\
\text { bow } \\
\mathrm{mm} / \mathrm{m}\end{array}$ & 3,00 & 1,71 & 1,4210 & 2,2117 \\
\hline $\begin{array}{l}\text { Roller } \\
\text { wave } \\
\text { distor- } \\
\text { tion }\end{array}$ & 0,3 & 0,14 & 0,1520 & 0,1355 \\
\hline Edge lift & 0,3 & 0,14 & 0,2883 & 0,1812 \\
\hline
\end{tabular}

\section{Conclusions}

Architectural glass is produced in large panes. During heat treatment, when it acquires certain desirable properties, both the overall and local bows are formed in it.

The flatness estimation of thermally toughened soda lime silicate safety glass was recognized by standards [1-4], which give the maximum allowed distortion value.

The proposed vision system allowed for the estimation of overall and local bows. Without assuming a statistical distribution for surface deviations, it was found that with a 
probability of $75 \%$, the given production panel will not exceed the maximum deviation value defined in the standards and in fig. 1. The results obtained in the studies confirm the possibility of using a developed machine vision inspection system in industrial environments.

\section{REFERENCES}

1. EN 12150-1: 2015 Glass in buildings - Thermally toughened soda lime silicate safety glass - Definition and description.

2.-EN 12150-2: 2004 Glass in building. Thermally toughened soda lime silicate safety glass - Evaluation of conformity/Product standard.

3. EN 572-1:2012+A1:2016 Glass in building. Basic soda-lime silicate glass products. Definitions and general physical and mechanical properties.

4. EN 572-2:2012 Glass in building. Basic soda lime silicate glass products. Float glass.

5. GGF Datasheet for the Quality of Thermally Toughened Soda Lime Silicate Safety Glass for Building. www.ionglass.co.uk. 